\title{
Species-specific phytoplankton growth rates via diel DNA synthesis cycles. V. Application to natural populations in Long Island Sound
}

\author{
Jeng Chang, Edward J. Carpenter
}

Marine Sciences Research Center, State University of New York, Stony Brook, New York 11794, USA

\begin{abstract}
A field experiment was conducted in Long Island Sound, USA, in July 1987 to test the ability of the cell cycle analysis method to estimate species-specific phytoplankton growth rates. The growth rates of 3 species - the diatom Leptocylindrus danicus and the dinoflagellates Prorocentrum triestinum and Dinophysis acuminata - were measured, and diffusion (cage) cultures were used in a parallel experiment to obtain independent estimates of growth rate. Growth rates estimated by the cell cycle method were 0.07 to $0.25 \mathrm{~d}^{-1}$ for $L$. danicus, 0.43 and $0.44 \mathrm{~d}^{-1}$ for $P$. triestinum, and 0.54 and $0.67 \mathrm{~d}^{-1}$ for $D$. acuminata. The variation was higher for $L$. danicus because the degree of synchrony in this species was low. Growth rates measured by the diffusion culture methods were about $0.1 \mathrm{~d}^{-1}$ different from the corresponding rates from cell cycle analysis. The attempt to use the frequency of double nucleated cells as a means to check the accuracy of growth rate estimates was not successful. The estimated growth rates fit the observed pattern of phytoplankton succession.
\end{abstract}

\section{INTRODUCTION}

To understand the structure and function of phytoplankton communities, an accurate method for estimating the growth rate of individual species is indispensable. The method of cell cycle analysis is one of several now used to estimate species-specific growth rate (Carpenter \& Chang 1988). In addition to identifying and measuring individual cells in natural water samples, an important advantage of this approach is the elimination of bottle incubation. This removes a major source of uncertainty, because the possible artifacts and other interferences linked to incubation can be excluded from data interpretation.

The basic concept which allows the cell cycle method to be used for growth rate estimation is the fact that a eukaryotic cell has to complete a number of cycle phases in a strict order for division. For unicellular organisms such as phytoplankton, the generation of daughter cells through cell division directly leads to population growth. In general, the cell cycle is composed of 4 phases with respect to the DNA content of each cell. The G1 phase is the first 'gap' stage, before the onset of DNA synthesis. Once DNA synthesis begins, the cell is said to be in the $S$ phase. The G2 phase is the second gap, between the $S$ phase and mitosis, and mitosis is named the $\mathrm{M}$ phase of cell cycle (for review see Chisholm 1981). Regardless of whether a cell population is synchronous or not, Smith \& Dendy (1962) showed that the instantaneous growth rate can be calculated from the fraction of the population in the $M$ phase (the $M$ phase fraction) and the duration of the $M$ phase. By averaging instantaneous growth rates over a 24 h cycle, McDuff \& Chisholm (1982) established an equation for estimating the daily mean growth rate in phytoplankton. Later, Carpenter \& Chang (1988) expanded on this idea and showed that the equation can include other cell cycle phases, as long as these phases are consecutive in the cell cycle and the combined process lasts until the end of mitosis. Such a segment of the cell cycle is known as a terminal event (Mitchison 1971), and the daily mean growth rate $(\mu)$ can be calculated from the fraction of a population which stays in a terminal event $X$ at time $t\left[f_{X}(t)\right]$ and from the duration of $\mathrm{X}\left(T_{\mathrm{X}}\right)$ :

$$
\mu=\frac{1}{n T_{\mathrm{X}}} \sum_{i=1}^{n} \ln \left[1+f_{\mathrm{X}}\left(t_{i}\right)\right]
$$

where $\mathrm{n}=$ number of samples taken in a $24 \mathrm{~h}$ cycle. Carpenter \& Chang's (1988) derivation also indicated that, if part of the cell population is synchronized, $T_{X}$ can be obtained from phase fraction curves, which are 
constructed by plotting fractions of 2 consecutive cell cycle phases against time during a 24 h cycle.

The initial verifications with isolated dinoflagellates have confirmed the effectiveness of both the DNA staining technique used to obtain phase fractions and the computational algorithm for growth rate estimation (Chang \& Carpenter 1988, Antia et al. 1990). However, concerns were raised about the performance of this method under conditions that violate the original assumptions, and about minor problems encountered in data analysis. A study with computer-simulated populations indicated that the cell cycle method estimates growth rate with an average deviation of $22 \%$ when measurement errors are taken into consideration (Chang \& Carpenter 1990). The same study revealed that, to generate smooth phase fraction curves from measured data points by curve fitting, both polynomial and periodic functions are acceptable techniques. The latter is more effective when more than one peak appears on a phase fraction curve, or when a peak locates near the beginning or the end of the $24 \mathrm{~h}$ sampling period. Situations such as ultradian growth, skewed cell cohort, and phase-specific cell loss have only minor effects on the accuracy of growth rate estimates (Chang 1989, Chang \& Carpenter 1990). If cell loss exists, the method of cell cycle analysis always estimates the intrinsic growth rate rather than the net growth rate (Chang 1989). These evaluations suggest that the method of cell cycle analysis is suitable for field applications.

In an attempt to apply the method of cell cycle analysis to the field, a study was conducted in Long Island Sound, New York, USA. The purpose was (1) to determine whether the single cell DNA content of each species can be measured successfully by microfluorometry, (2) to determine if a series of DNA histograms with rhythmic change in shape can be observed for each species, (3) to determine whether a reasonable growth rate can be generated from phase fraction curves, and (4) to determine if measuring $M$ phase fractions separately can be used to check the accuracy of growth rate estimation. Phytoplankton cages (Owens et al. 1977. Fumas 1982) were used in parallel experiments to obtain species-specific growth rates independently, and the results were compared to the growth rate estimates from cell cycle analysis.

\section{MATERIALS AND METHODS}

A cruise to Long Island Sound was conducted on the RV 'Onrust' from 9 to 10 July 1987 The sampling site was located at $41^{\circ} 00^{\prime} \mathrm{N}$ and $73^{\circ} 07^{\prime} \mathrm{W}$. The ship was allowed to drift within the area bounded by the $40 \mathrm{~m}$ isobath. Sunrise and sunset on 9 July were at 05:30 and
20:26 h Eastern Daylight-Savings Time, respectively. Time reported in this study is in the form of environmental time, with sunrise on 9 July as Hour 0 .

On 9 July, water samples for determination of ambient phytoplankton abundance were collected from $1 \mathrm{~m}$ depth and preserved in Lugol's solution (Parsons et al. 1984). Depth-integrated water samples collected on 29 May, 11 and 19 June, and 1 July from the same location were kindly provided by W. T. Peterson. Each of these samples contained an equal-volume mixture from 1, 3, and $5 \mathrm{~m}$ depth. Phytoplankton cells were concentrated from 50 to $0.5 \mathrm{ml}$ by centrifugation, and enumerated at $100 \times$ or $400 \times$ using a Sedgewick-Rafter counting chamber. Three species of phytoplankton were selected for cell counts and cell cycle analysis. They include a diatom, Leptocylindrus danicus Cleve, and 2 dinoflagellates, Prorocentrum triestinum Schiller ( = $P$. redfeldi Bursa) and Dinophysis acuminata Claparède. We did not make efforts to distinguish cells of Leptocylindrus from Cerataulina (C. bergonii $\mathrm{H}$. Péragallo) in water samples collected between 29 May and 1 July because these samples had been stored for a prolonged period before being enumerated.

Phytoplankton samples for cell cycle analysis were collected every 1 to $2 \mathrm{~h}$ on 9 and 10 July from $1 \mathrm{~m}$ depth with a 20 um mesh plankton net with a mouth diameter of $15 \mathrm{~cm}$. Samples were centrifuged immediately, and cells were preserved in chilled methanol. The procedures of DNA staining and quantification have been described previously (Chang \& Carpenter 1988). Detailed description of data analysis and growth rate calculation can be found in Carpenter \& Chang (1988) and Chang \& Carpenter (1990). Both polynomial and periodic functions were used to fit a smooth curve to the measured cell cycle phase fractions for the purpose of estimating the duration of the $\mathrm{S}$ and the $\mathrm{G} 2+\mathrm{M}$ phases, but the iterative correction was not incorporated in the computation (Chang \& Carpenter 1990).

Because fixed sampling intervals are difficult to maintain in field conditions, weighted means of phase fractions were used to calculate growth rates (Chang \& Carpenter 1985). The modified Eq. (1) becomes

$$
\mu=\frac{1}{24 T_{X}} \sum_{i=1}^{n}\left(t_{s}\right)_{i} \times \ln \left[1+f_{X}\left(t_{l}\right)\right]
$$

where $\left(t_{s}\right)_{i}=$ sampling interval of sample $i$ measured in hours.

Two growth rates from the method of cell cycle analysis were estimated for each species according to Eq. (2). For one estimate, we used the combined $S, G 2$, and $M$ phase as the terminal event, and measured the duration term by monitoring the diel change of the $S$ and the $\mathrm{G} 2+\mathrm{M}$ phase fractions $\left[\mathrm{f}_{\mathrm{S}}(t)\right.$ and $\left.f_{\mathrm{G} 2 \mathrm{M}}(t)\right]$.

For the second estimate, we used G2 and $M$ phases as the terminal event, and obtained the duration term 
from additionally measured $M$ phase fractions. During the process of microfluorometry, the number of double nucleated cells was recorded to determine the $M$ phase fraction, or $f_{\mathrm{M}}$. The $\mathrm{G} 2$ phase fraction, $f_{\mathrm{G} 2}$, was obtained from $\left(f_{\mathrm{C} 2 \mathrm{M}}-f_{\mathrm{M}}\right)$, where $f_{\mathrm{C} 2 \mathrm{M}}$ was the $\mathrm{G} 2+\mathrm{M}$ phase fractions extracted from the DNA histogram of the same sample.

In the phytoplankton cage experiment, unconcentrated water samples were incubated in situ after grazers were removed by filtration (100 $\mu \mathrm{m}$ Nitex mesh). Each incubation container had a volume of $115 \mathrm{ml}$, and its opening was covered by a $0.5 \mu \mathrm{m}$ Nuclepore filter to allow free exchange of nutrients and waste with the environment (Furnas 1982). A series of 6 cages were incubated at a depth of $1 \mathrm{~m}$. Every $4 \mathrm{~h}$, a cage was retrieved and its contents were fixed with Lugol's solution for later determination of cell density. Growth rates were calculated with the cell counts at the beginning and end of a $22 \mathrm{~h}$ in situ incubation period (Guillard 1973).

\section{RESULTS}

The most abundant phytoplankters at the sampling site were a group of chain-forming diatoms composed of species in the genera Leptocylindrus and Cerataulina (Fig. 1). From the end of May to the beginning of July 1987, diatoms were 5 to 10 times more abundant than any other species within the same size range. The abundance of this group started to decrease in early July, and C. bergonii almost disappeared in the samples collected on 9 July. Concurrently, the abundance of several dinoflagellates, including Prorocentrum triestinum, Dinophysis acuminata, and Amphidinium crassum Lohmann, had increased since 19 June. The athecate dinoflagellate, A. crassum, was abundant in Lugolpreserved samples but not in net samples.

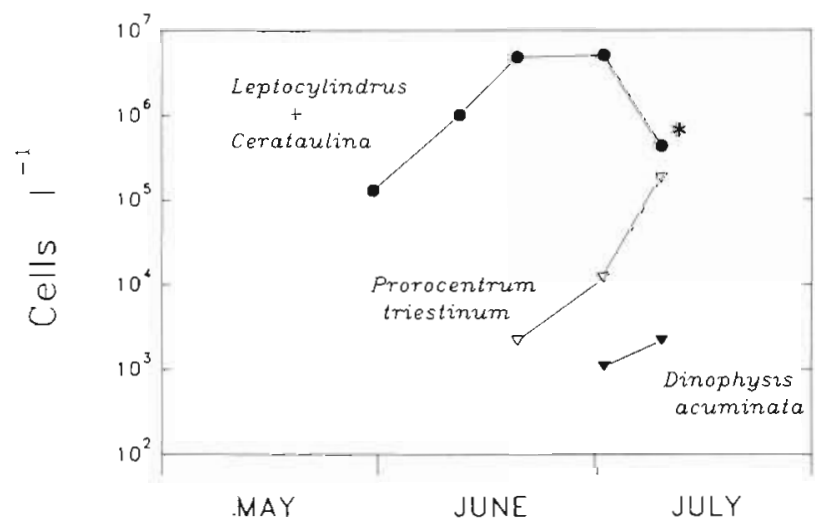

Fig. 1. Natural abundances of major microphytoplankton species in central Long Island Sound from May to July 1987. Leptocylindrus: $L$. danicus; Cerataulina: $C$ bergonii. ': Abundance of $L$. danicus only
During the $24 \mathrm{~h}$ sampling cycle on Long Island Sound, water temperature at $1 \mathrm{~m}$ depth varied between 19.5 and $21.5^{\circ} \mathrm{C}$. The ambient abundance of all 3 species varied more than an order of magnitude and showed a similar oscillation pattern, with elevated population densities around Hour 6 and low densities between Hours 12 and 24 (Fig. 2). In the phytoplankton cage experiment, cell counts of Prorocentrum triestinum increased from $1.8 \times 10^{5}$ to $2.9 \times 10^{5}$ cells $]^{-1}$ in the cage incubated in situ for $22 \mathrm{~h}$, but a temporary decrease was found around the time of sunset (Fig. 2). Cell density of Leptocylindrus danicus and Dinophysis acuminata, on the other hand, did not change much during incubation. Many empty frustules of the former species, sometimes more abundant than healthy cells, were observed under the microscope. Growth rates estimated with net increases in population densities were $0.51 \mathrm{~d}^{-1}$ for $P$. triestinum, and $0.21 \mathrm{~d}^{-1}$ for $L$. danicus (Table 1). As for $D$. acuminata, high variation
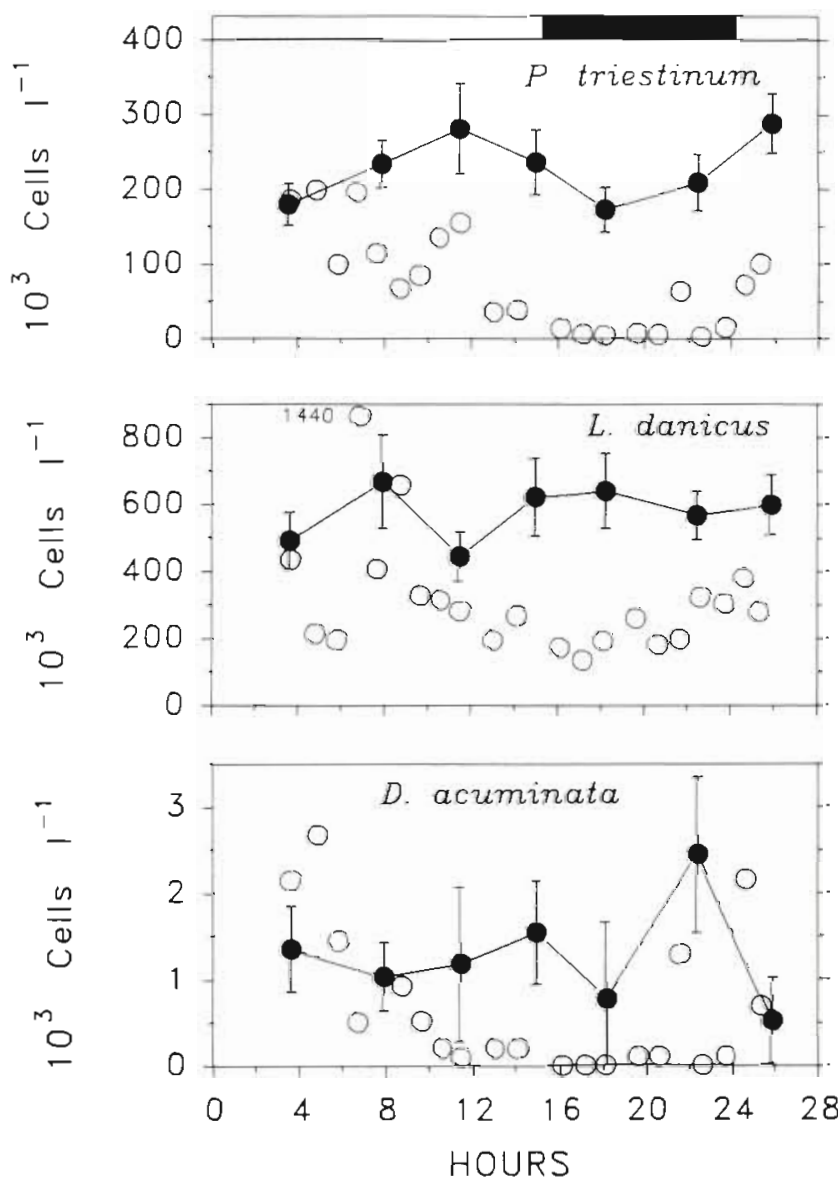

Fig. 2. Prorocentrum triestinum, Leptocylindrus danicus, and Dinophysis acuminata. Population densities in phytoplankton cages $(\bullet)$ and ambient water $(0)$ at different times during the field experiment. Error bar $=1$ standard deviation. Hour $0=$ 05:30 h Eastern Daylight Savings Time, 9 July 1987. Heavy horizontal bar at top indicates period between sunset and sunrise 
Table 1 Growth rates $\left(\mathrm{d}^{-1}\right)$ estimated from the phytoplankton cage experiment and several methods of cell cycle analysis

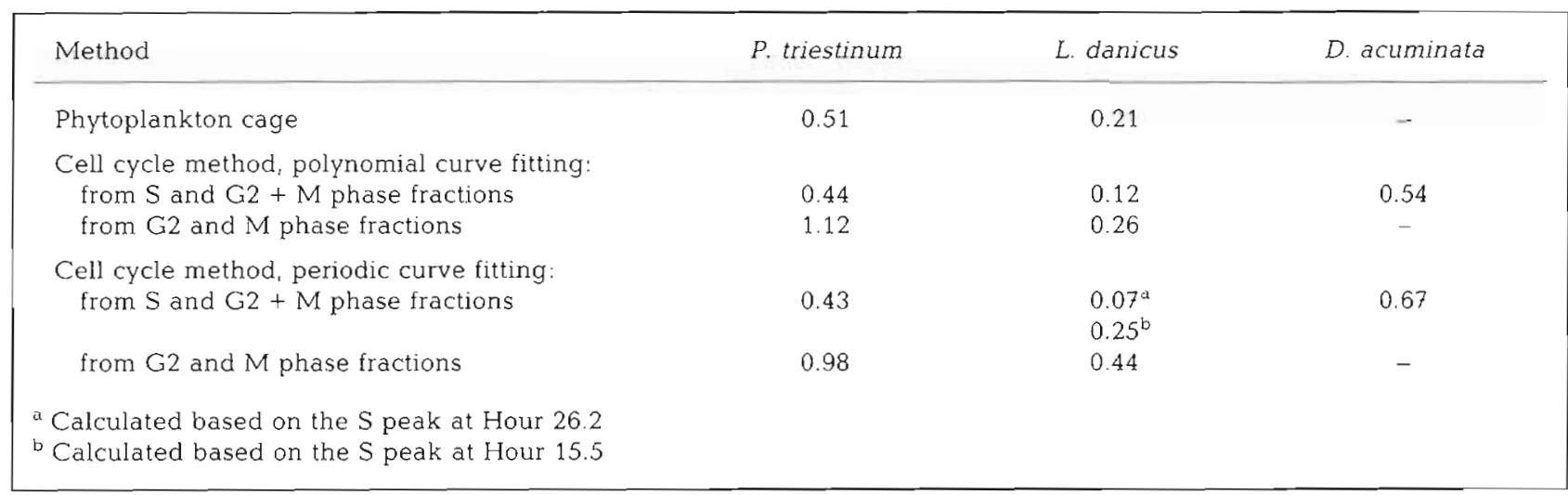

in cell counts due to low abundance, as well as the irregular pattern shown by the last 3 data points, prevented us from obtaining a meaningful growth rate (Fig. 2).

Nuclei of Prorocentrum triestinum were round to oval in shape. Well-formed DNA histograms with measurement CV's (coefficients of variation) around $11 \%$ were readily obtainable. The time required for measuring 300 cells from a field sample was about 3 to $4 \mathrm{~h}$. For this species, the $\mathrm{S}$ phase fraction reached a maximum near the time of sunset (Fig. 3). The G2+M peak occurred

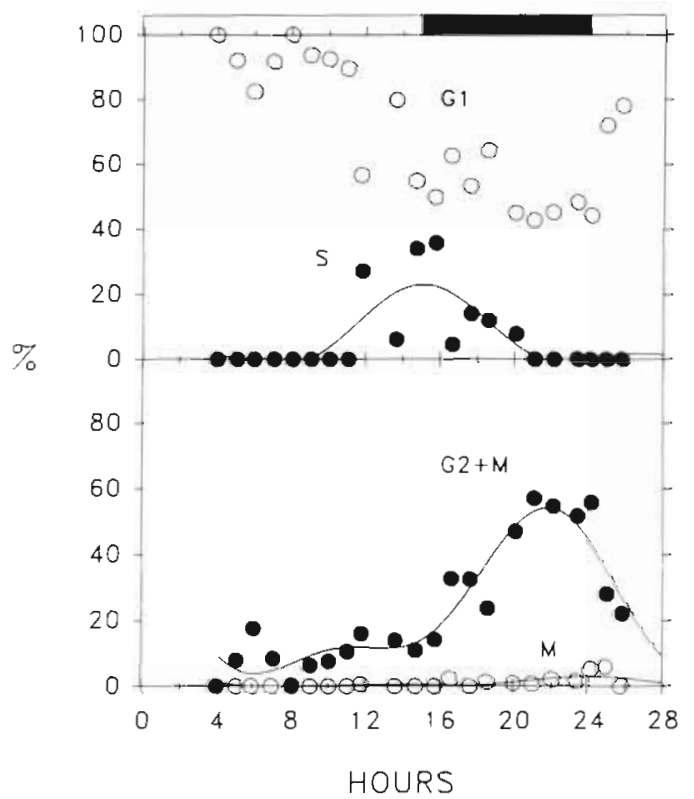

Fig. 3. Prorocentrum triestinum. Phase fractions from field samples. Upper panel: G1 phase fractions ( ) and S phase fractions ( $\bullet$ at different times. The continuous curve $(-)$ is a periodic function fitted to measured $S$ phase fractions. Lower panel: $\mathrm{G} 2+\mathrm{M}(\bullet)$ and $\mathrm{M}(\mathrm{O})$ phase fractions. The continuous curves (-) are fitted periodic functions. Hour $0=05: 30 \mathrm{~h}$ Eastern Daylight Savings Time, 9 July 1987 Heavy horizontal bar at top indicates dark period from sunset to sunrise late in the dark period, and mitosis started near the time of sunrise. Polynomial and periodic curve fitting estimated virtually the same growth rate (Table 1 ). Durations of $S$ and $G 2+M$ phases were 2.8 and $10.8 \mathrm{~h}$, respectively, according to periodic curve fitting.

The abundance of double nucleated Prorocentrum triestinum peaked in the early morning (Fig. 3). A sharp decline in the $\mathrm{G} 2+\mathrm{M}$ fraction was observed at the same time. When fitted curves were used to locate peaks, the time lag between the $G 2$ peak and the $M$ peak was only about $2 \mathrm{~h}$. Consequently, very high growth rates of 1.12 and $0.98 \mathrm{~d}^{-1}$ emerged from the computational procedure (Table 1).

The measurement CV was about $13 \%$ for histograms of Leptocylindrus danicus. The $\mathrm{S}$ and the $\mathrm{G} 2+\mathrm{M}$ phase fractions remained low throughout the $24 \mathrm{~h}$ cycle (Fig.

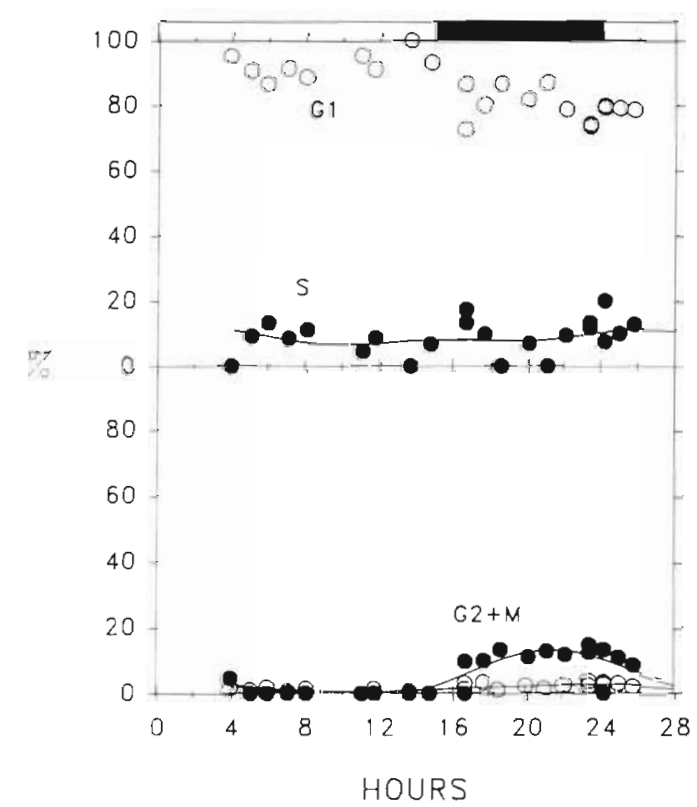

Fig. 4. Leptocylindrus danicus. Phase fractions from field samples. Symbols as in Fig. 3 
4). Their values seldom exceeded $20 \%$ of the population. The $\mathrm{G} 2+\mathrm{M}$ phase fractions formed a recognizable peak near the end of the dark period. The $\mathrm{S}$ phase fractions, however, did not show a well-defined peak. Different curve fitting methods generated peaks at different time points. The polynomial regression suggested an S peak near Hour 10. On the other hand, curve fitting with periodic functions suggested 2 peaks with similar amplitudes at Hours 15 and 26 respectively. As a result, the estimated growth rate of $L$. danicus was $0.07,0.12$, or $0.25 \mathrm{~d}^{-1}$ depending on which function was used to fit data points and which peak was used to calculate the duration term (Table 1).

Mitotic cells of Leptocylindrus danicus were detected in most samples. This indicated that cell division was occurring throughout the day. A mild peak, which coincided with the decline of the G2 phase fractions, did appear in the early morning (Fig. 4). The growth rates estimated from $G 2$ and $M$ phase fractions was twice those estimated from $S$ and $G 2+M$ fractions (Table 1).

Although the natural abundance of Dinophysis acuminata was low, enough cells were found in the net samples for DNA histogram construction and cell cycle analysis. The measurement $\mathrm{CV}$ was about $13 \%$ for histograms of this species. Similar to Prorocentrum triestinum, the $\mathrm{S}$ and the $\mathrm{G} 2+\mathrm{M}$ peaks were observed near sunset and sunrise, respectively (Fig. 5). Different curve fitting strategies estimated the growth rate as 0.54 and $0.67 \mathrm{~d}^{-1}$ (Table 1). The phase durations were estimated to be ca $2 \mathrm{~h}$ for the $\mathrm{S}$ phase and 9 to $11 \mathrm{~h}$ for the $G 2+M$ phase. The pattern of the $M$ phase fraction

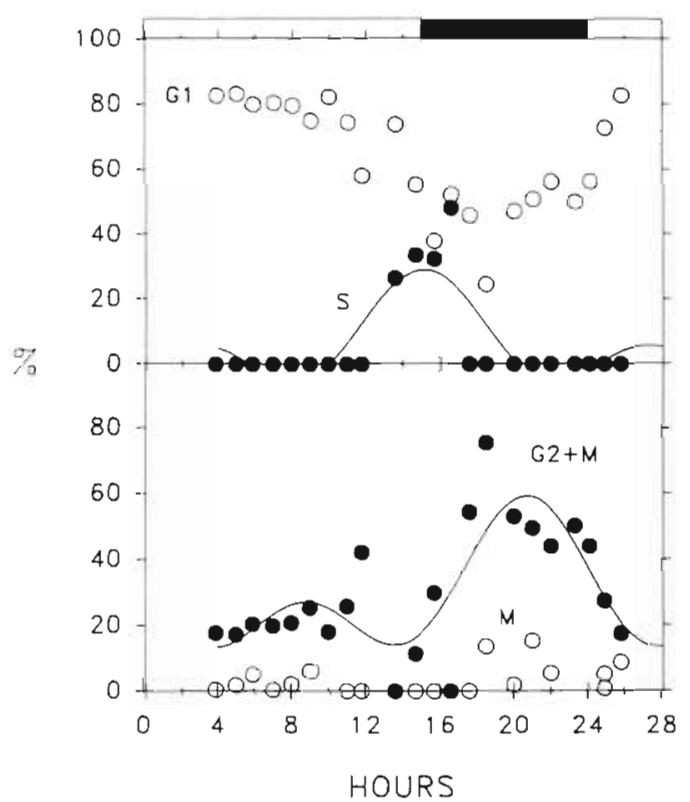

Fig. 5. Dinophysis acuminata. Phase fractions from field samples. Symbols as in Fig. 3 showed several sporadic high values instead of a wellformed peak (Fig. 5). No growth rate was generated with this set of $M$ phase fractions

\section{DISCUSSION}

We found no major difficulties in applying the method of cell cycle analysis to natural phytoplankton populations. No species was observed to have poorly stained nuclei as reported by Zachleder \& Cepák (1987). The DNA content of each cell was easily quantified by microfluorometry, and phase fraction curves (Figs. 3 to 5) similar to those from laboratory experiments (Chang \& Carpenter 1988) can be constructed readily. The measurement CV's of field samples (11 to $13 \%$ ) are somewhat higher than CV's of phytoplankton cultures ( 6 to $9 \%$ ). The cause is unclear, but some minor adjustments in the staining procedure made recently have reduced measurement $\mathrm{CV}$ in natural dinoflagellates to between 8 and $11 \%$ (Chang unpubl.)

An abundant species, Amphidinium crassum, in Lugol-fixed samples was not found in net samples preserved in methanol. This athecate dinoflagellate, with a typical width of about $12 \mu \mathrm{m}$, may not have been effectively retained by our $20 \mu \mathrm{m}$ net. Another possibility is that methanol is a poor preservative for this species. Similar observations have been made for several other dinoflagellates (Cetta \& Anderson 1990), and pre-fixation with formaldehyde or glutaraldehyde before methanol extraction may be used as a remedy (Vaulot et al. 1989, Cetta \& Anderson 1990). A short period of formaldehyde fixation up to $24 \mathrm{~h}$ has been shown to have no undesirable effect on DNA quantification in Heterocapsa triquetra (Chang 1989).

Both DNA synthesis and cell division of the dinoflagellates occurred at distinct periods during a $24 \mathrm{~h}$ cycle. (Figs. $2 \& 5$ ). Although DNA synthesis in Prorocentrum triestinum has been reported as continuous throughout the cell cycle on some occasions (Karentz 1983, Costas et al. 1987), a similar pattern was not observed in this natural population. The 2 curve fitting techniques generated similar growth rate estimates for $P$. triestinum and Dinophysis acuminata (Table 1). This result agrees with conclusions from the computer simulation study (Chang \& Carpenter 1990).

In Leptocylindrus danicus, the inconsistency among growth rate estimates was apparently caused by the lack of a distinguishable peak in the $\mathrm{S}$ phase fractions (Fig. 3). When the degree of synchrony is low and a population is not growing, a broad peak in the S fraction curve may be obscured by the noise from the deconvolution procedure (Baisch et al. 1982, Chang \& Carpenter 1990). A low degree of synchrony is common 
for some diatom species. Multipeaked division rhythmicity is the typical response to oscillating environmental conditions in these species (Nelson \& Brand 1979, Olson \& Chisholm 1983). Although the cell cycle method is able to estimate growth rates in such populations, difficulties will be inevitable when peaks cannot be reliably located with curve fitting techniques (Chang \& Carpenter 1990). The solution may lie in several recently discovered cell cycle markers. One example is cyclin, a group of cell cycle regulatory proteins, which has recently been visualized in yeast by immunostaining (Booher et al. 1989). Since the presence of these nuclear proteins is tightly associated with specific cell cycle phases, they may be used to replace DNA quantification in the future, and their use may reduce the uncertainty of phase fraction estimation in phytoplankton.

Using the $M$ phase fraction curve to check the consistency of the duration terms should increase the reliability of estimated $\mu$ 's. However, some controversial results were noticed in this field experiment (Table 1). In Prorocentrum triestinum, the duration of the $M$ phase was estimated to be $12 \mathrm{~min}$ based on $f_{\mathrm{G} 2}$ and $f_{\mathrm{M}}$ (Fig. 3). This value should be regarded as an underestimate because electron micrographs of a synchronized culture revealed that the time required from nuclear division to cytokinesis is $1 \mathrm{~h}$ in this species (Costas et al. 1987). In Dinophysis acuminata, several sporadic high values of $f_{M}$ imply that substantial error may be involved in the determination of this phase fraction. Mitotic cells are always rare in a population, and up to 1000 cells may be required to obtain accurate $f_{\mathrm{M}}$ 's (Weiler \& Eppley 1979). Our sample size (250 to 300 cells) was adequate for the construction of DNA histograms but may be too small to obtain reliable $f_{M}$ 's. Also, the sampling interval was probably too long to reveal the correct peak position of the $M$ phase for such a short event. Our results indicated that recording the frequency of dividing cells during DNA quantification does not improve the accuracy of growth rate estimation.

The observed diel variation in ambient abundance of the 3 phytoplankters (Fig. 2) could have resuited from the drift of the research vessel through a large patch. It is possible that we sampled from the center of the patch during the daytime but from the rim during the night. For Prorocentrum triestinum and Dinophysis acuminata, the major information for calculating their is via cell cycle analysis came from the night period (Figs. $3 \& 5$ ), and thus the estimated growth rates are more likely to reflect their population growth at the patch's rim.

The same variation in ambient phytoplankton abundance can also be explained by diel changes in grazing pressure (Dam 1986, Bautista et al. 1988).
According to our computer simulation study and laboratory grazing experiments, cell loss due to grazing or other factors does not introduce bias into the intrinsic growth rates estimated by cell cycle analysis (Chang 1989). This statement remained true even when the loss was differentially placed on cells in a specific cell cycle phase. Furthermore, the diel pattern of grazing pressure measured simultaneously during the sampling day does not support the view that the observed change in phytoplankton abundance was entirely due to grazing (Dam Guerrero 1989).

For the 2 species of dinoflagellates, the diel change in population densities could be a result of vertical migration, since our sampling depth was fixed at $1 \mathrm{~m}$. If a cell's migrating capability does not depend upon its stage in the cell cycle, then the subpopulation remaining near the surface can give us an unbiased estimation of cell cycle phase fraction, and the estimated growth rate should not be affected by vertical migration. If only cells at a certain stage of their life cycle migrate to a greater depth (e.g. Pyrocycstis fusiformis and $P$. noctiluca; Swift et al. 1976), the phase fraction and the growth rate obtained from samples taken at a fixed depth may become biased. A possible remedy for this problem is to collect depth-integrated samples by towing a plankton net vertically. Based on a study conducted in the Long Island coastal area (Staker \& Bruno 1980), Dinophysis acuminata did not vertically migrate. In Prorocentrum triestinum, vertical migration was evident, but the range of migration was only $2.7 \mathrm{~m}$.

Growth rates obtained from the phytoplankton cages and those from cell cycle analysis differed by about $0.1 \mathrm{~d}^{-1}$ (Table 1). It appears that the 2 methods agree with each other at least to the extent that we can conclude that Leptocylindrus danicus had a low growth rate and Prorocentrum triestinum had a moderately high growth rate on the day of sampling. In $P$. triestinum, the decrease in cell number around sunset was probably caused either by grazers that were not removed by the $100 \mu \mathrm{m}$ mesh or by bottle effects (Fig. 2).

Compared to the phytoplankton cage method of measuring growth rate, cell cycle analysis provides several important advantages. The cell cycle method can measure growth rates of less abundant species, such as Dinophysis acuminata, in the natural environment as long as enough cells can be collected by towing a plankton net. The same procedure cannot be used with methods that require incubation. Secondly, the cell cycle method is more effective with species which do not grow well in enclosures. For example, during the cage incubation, the cell number of $D$. acuminata showed no increase, but cell cycle analysis revealed that the population was growing actively (Figs. $2 \& 5$ ). In addition, the cell cycle method is less 
sensitive to the existence of cell loss, so it reduces potential problems for data interpretation. One such problem can be found in the cage measurement of Prorocentrum triestinum, which showed a temporary decrease during the incubation (Fig. 2). Although this is a common phenomenon found in many other healthy populations (Nelson \& Brand 1979), it does raise the question about whether the growth rate obtained this way should be treated as net or intrinsic.

Judging from the long-term change in phytoplankton abundance, the species-specific growth rates from the cell cycle analysis are consistent with the observed successional pattern (Fig. 1). In Long Island Sound, June is traditionally a period of transition from a wellmixed water column to a stratified state, and from a diatom-dominated community to one dominated by dinoflagellates (Riley \& Conover 1967, Capriulo \& Carpenter 1983, Peterson 1986). In 1987, the termination of the diatom bloom not only was indicated by the cell counts (Fig. 1) but also was reflected in the chlorophyll a $(\mathrm{chl} \mathrm{a})$ concentration at the sampling site. From 1 to 7 July, chl a concentration at $1 \mathrm{~m}$ depth dropped from ca 6 to $2 \mu \mathrm{g} \mathrm{l}^{-1}$, and the concentration at $10 \mathrm{~m}$ dropped from ca 10 to $3 \mu \mathrm{gl}^{-1}$ (Dam Guerrero 1989). As a result, it was reasonable to observe that the dominant diatom, Leptocylindrus danicus, had a slow growth rate on 9 July. Also, the relatively high growth rates of Prorocentrum triestinum and Dinophysis acuminata reflected presumably active growth, when abundance of the dinoflagellates started to increase.

Acknowledgement. We thank H. G. Dam for his help and cooperation on the joint cruise to Long Island Sound. The cost of RV 'Onrust' was provided by the Marine Science Research Center (MSRC). Some technical support was provided by $M$. L. Reeder This research was supported by NSF grant OCE8816584 and ONR grant N0001490J1803 to E.J.C. Contribution 826 from the MSRC.

\section{LITERATURE CITED}

Antia, A. N., Carpenter, E. J., Chang, J. (1990). Speciesspecific phytoplankton growth rates via diel DNA synthesis cycles. III. Accuracy of growth rate measurement in the dinoflagellate Prorocentrum minimum. Mar. Ecol. Prog. Ser. 63: 273-279

Baisch, H., Beck, H.-P., Christensen, I. J., Hartmann, N. R., Fried, J., Dean, P. N., Gray, J. W., Jett, J. H. (1982). A comparison of mathematical methods for the analysis of DNA histograms obtained by flow cytometry. Cell Tissue Kinetics 15: 235-249

Bautista, B., Rodriguez, V., Jimenez, F. (1988). Short-term feeding rates of Acartia grani in natural conditions: diurnal variation. J. Plankton Res, 10: 907-920

Booher, R. N., Alfa, C. E., Hyams, J. S., Beach, D. H. (1989). The fission yeast cdc2/cdc13/suc1 protein kinase: regulation of catalytic activity and nuclear localization. Cell 58: 485-497
Capriulo, G. M., Carpenter, E. J. (1983). Abundance, species composition and feeding impact of tintinnid micro-zooplankton in central Long Island Sound. Mar. Ecol. Prog. Ser 10: $277-288$

Carpenter, E. J., Chang, J. (1988). Species-specific phytoplankton growth rates via diel DNA synthesis cycles. I. Concept of the method. Mar Ecol. Prog. Ser 43: 105-111

Cetta, C. M., Anderson, D. M. (1990). Cell cycle studies of the dinoflagellates Gonyaulax polyhedra Stein and Gyrodinium uncatenum Hulburt during asexual and sexual reproduction. J. exp. mar Biol. Ecol. 135: 69-84

Chang, J. (1989). Estimating species-specific phytoplankton growth rates by cell cycle analysis. Ph.D. thesis, Marine Sciences Research Center, State University of New York at Stony Brook

Chang, J., Carpenter, E. J. (1985). Blooms of the dinoflagellate Gyrodinium aureolum in a Long Island estuary: box model analysis of bloom maintenance. Mar. Biol. 89: 83-93

Chang, J., Carpenter, E. J. (1988). Species-specific phytoplankton growth rates via diel DNA synthesis cycles. II. DNA quantification and model verification in the dinoflagellate Heterocapsa triquetra. Mar. Ecol. Prog. Ser. 44: 287-296

Chang, J., Carpenter, E. J. (1990). Species-specific phytoplankton growth rates via diel DNA synthesis cycles. IV. Evaluation of the magnitude of error with computersimulated cell populations. Mar. Ecol. Prog. Ser 65: 293-304

Chisholm, S. W. (1981). Temporal patterns of cell division in unicellular algae. In: Platt, T (ed.) Physiological bases of phytoplankton ecology. Can. Bull. Fish. Aquat. Sci. 210: $150-181$

Costas, E., Suarez, E., Bao, R., Alvarez, C. (1987). Cambios de la ultraestructura nuclear durante el ciclo celular de Prorocentrum triestinum Schiller, 1918 (Dinophyceae). Investigación pesq. 51 459-466

Dam, H.G. (1986). Short-term feeding of Temora longicornis Muller in the laboratory and the field. J exp. mar. Biol. Ecol. 99: 149-161

Dam Guerrero, H. G. (1989). The dynamics of copepod grazing in Long Island Sound. Ph.D. thesis, Marine Sciences Research Center, State University of New York at Stony Brook

Furnas, M. J. (1982). An evaluation of two diffusion culture techniques for estimating phytoplankton growth rate in situ. Mar Biol. 70: 63-72

Guillard, R. R. L. (1973). Division rates. In: Stein, J. R. (ed.) Handbook of phycological methods: culture methods and growth measurements. Cambridge University Press, Cambridge, p. 289-312

Karentz, D. (1983). Patterns of DNA synthesis and cell division in marine dinoflagellates. J. Protozool. 30: 581-588

McDuff, R. E., Chisholm, S. W. (1982). The calculation of in situ growth rates of phytoplankton populations from fractions of cells undergoing mitosis: a clarification. Limnol. Oceanogr. 27: 783-788

Mitchison, J. M. (1971). The biology of cell cycle. Cambridge University Press, London

Nelson, D. M., Brand, L. E. (1979). Cell division periodicity in 13 species of marine phytoplankton on a light:dark cycle. J. Phycol. 15: 67-75

Olson, R. J., Chisholm, S. W. (1983). Effects of photocycles and periodic ammonium supply on three marine phytoplankton species. I. Cell division patterns. J. Phycol 19: $522-528$

Owens, O. v.-H., Dresler, P., Crawford, C. C., Tyler, M. A., Seliger, H. H. (1977). Phytoplankton cages for the meas- 
urement in situ of the growth rates of mixed natural population. Chesapeake Sci. 18: 325-333

Parsons, T R., Takahashi, M., Hargrave, B. (1984). Biological oceanographic processes, 3rd edn. Pergamon Press, Oxford

Peterson, W. T (1986). The effects of seasonal variation in stratification on plankton dynamics in Long Island Sound In: Bowman, M. J., Yentsch, C. M., Peterson, W. T (eds.) Tidal mixing and plankton dynamics. Springer-Verlag, Berlin, p. 297-320

Riley, G. A., Conover, S. M. (1967). Phytoplankton of Long Island Sound 1954-1955. Bull. Bingham oceanogr. Coll. 19: $5-34$

Smith, C. L., Dendy, P. P. (1962). Relation between mitotic index, duration of mitosis, generation time and fraction of dividing cells in a cell population. Nature Lond. 193 : 555-556

This article was presented by M. Levandowsky, New York New York, USA
Staker, R. D., Bruno, S. F. (1980). Diurnal vertical migration in marine phytoplankton. Botanica mar. 23: 167-172

Swift, E., Stuart, M., Meunier, V (1976). The in situ growth rates of some deep-living oceanic dinoflagellates: Pyrocystis fusiformis and Pyrocystis noctiluca. Limnol. Oceanogr. 21: $418-426$

Weiler, C. S., Eppley, R. W. (1979). Temporal pattern of division in the dinoflagellate genus Ceratium and its application to the determination of growth rate. J. exp. mar. Biol. Ecol. 39: 1-24

Vaulot, D., Courties, C., Partensky, F. (1989). A simple method to preserve oceanic phytoplankton for flow cytometric analyses. Cytometry 10: 629-635

Zachleder, V., Cepák, V (1987). Visualization of DNA containing structures by fluorochrome DAPI in those algal cells which are not freely permeable to the dye. Arch. Hydrobiol. (Suppl.) 78: 157-168

Manuscript first received: May 1, 1991

Revised version accepted: October 15, 1991 